\title{
ICE VOLGANOES OF THE LAKE ERIE SHORE NEAR DUNKIRK, NEW YORK, U.S.A.
}

\author{
By R. K. Fahnestock, D. J. Crowley, M. Wilson and H. Schneider \\ (Department of Geology, State University College, Fredonia, New York 14063, U.S.A.)
}

Abstract. Conical mounds of ice have been observed to form in a few hours during violent winter storms along the edge of shore-fast ice near Dunkirk, New York. They occur in lines which parallel depth contours, and are evenly spaced in the manner of beach cusps. The height and spacing of mounds and number of rows vary from year to year depending on such factors as storm duration and intensity, and the position of the
edge of the shore-fast ice at the beginning of the storm.

The evenly sloping conical mounds have central channels which increase in width lakeward. The ice between the channels forms headlands above the lake surface. Spray-formed levees develop along the headlands and slope gently away from the lake margin. Lake marginal walls of ice are usually vertical.

Spray, slush and ice blocks are ejected over the cone as each successive wave is focused by the converging channel walls. Ice blocks, interlayered with frozen slush and dirt, form bedding paralleling the sloping surface of cones, headlands and levees. These features are here termed "ice volcanoes" because their origin
is in so many ways analogous to that of true volcanoes.

RÉsumé. Volcan de glace sur les bords du lac Erie près de Dunkirk, New York, U.S.A. On a observé la formation en quelques heures, au cours de violentes tempêtes hivernales, de mamelons coniques de glace le long du bord de la glace ferme près de Dunkirk, New York. Ils sè présentent alignés selon de larges courbes parallèles et sont régulièrement espacés à la manière des barkanes de sable sur les plages. La hauteur et l'espacement des mamelons, le nombre des rangées, varient d'une année à l'autre au gré de facteurs tels que la durée de l'intensité des tempêtes et la position de la ligne de glace ferme au début de la perturbation.

La distribution régulière des mamelons coniques ménage des couloirs centraux qui croissent en largeur en allant vers le lac. La glace entre les couloirs forme des caps au-dessus de la surface du lac. Des promontoires formés par les jets d'embruns se développent le long des parois des caps, le niveau de ces promontoires s'abaissant progressivement lorsqu'on s'éloigne de la rive du lac. Les falaises de glace le long des rives du lac
sont généralement verticales.

Des embruns, de la boue et des fragments de glace sont éjectés par dessus les cones par chaque vague successive et focalisés par les murs convergents des couloirs. Les fragments de glace entrecoupés de niveaux d'embruns gelés et de poussières forment des lits parallèles à la surface inclinée des cones, des caps et des promontoires. Ces formations sont appelées volcans de glace à cause de leur origine à bien des égards, analogue à celle des véritables volcans.

Zusammenfassung. Eisvulkane am Ufer des Erie-Sees nahe Dunkirk, New York, U.S.A. Nahe bei Dunkirk, New York, wurden kegelförmige Eiswälle beobachtet, die sich während heftiger Winterstürme an uferfesten Eisrändern in wenigen Stunden bilden. Sie treten in Reihen parallel zu Tiefenlinien auf und sind gleichmässig wie Strandrippeln angeordnet. Die Höhe und Verteilung der Wälle und die Anzahl ihrer Reihen schwanken von Jahr zu Jahr in Abhängigkeit von Faktoren wie Sturmdauer und -stärke sowie Lage des uferfesten Eisrandes bei Beginn des Sturmes.

Die gleichmässig geneigten, kegelförmigen Wälle haben zentrale Kanäle, die seewärts an Breite zunehmen. Das Eis zwischen den Kanälen ragt über die Seeoberfläche empor. Von Gischt gebildete Wallkronen entwickeln sich entlang der Vorwälle und fallen flach gegen das Seeufer ab. Eiswälle am Seeufer sind
gewöhnlich vertikal.

Gischt, Schlamm und Eisblöcke werden über die Kegelkronen geschleudert, da jede nachfolgende Welle von den konvergierenden Kanalwänden ausgerichtet wird. Eisblöcke mit gefrorenen Schlamm- und Schmutzschichten bilden eine Unterlage parallel zur Oberflächenneigung der Kegel, Vorwälle und Kronen. Diese Erscheinungen werden hier "Eisvulkane" genannt, weil ihre Bildung der echter Vulkane ausgesprochen

\section{INTRODUCTION}

Volcano-like, conical mounds of ice up to $5 \mathrm{~m}$ high form each winter along portions of the southern shore of Lake Erie and Lake Ontario. Particularly large and regular examples of ice volcanoes* form on the west side of Point Gratiot at Dunkirk, New York, when the lake is open, and a shelf of ice is attached to the shore.

* Valid objections have been raised to the terms volcanoes, mounds, cones and even dunes as they are known at Presque Isle State Park, Erie, Pennsylvania, where prominent permanent signs warn of the danger of trespass.
"Ice volcano" has been adopted in this paper as most descriptive of form and process. 
When observed in active formation, eruptions of slush, ice and spray spouted two or more times the height of the cones. In some cases this was $10 \mathrm{~m}$ or more in the air. Flowing, sliding and rolling down the flanks of the cone, the ice was added rapidly. Accumulation of some of the larger cones is a matter of a few hours to a few days at most. At Dunkirk they occur in linear groups parallel to depth contours. In December 1970, there were three rows ranging from less than a meter in height near shore to $5 \mathrm{~m}$ in height $50 \mathrm{~m}$ offshore (Fig. I). During mid-January 1972 a single row of irregularly spaced, poorly shaped ice volcanoes was built overnight about $50 \mathrm{~m}$ offshore.

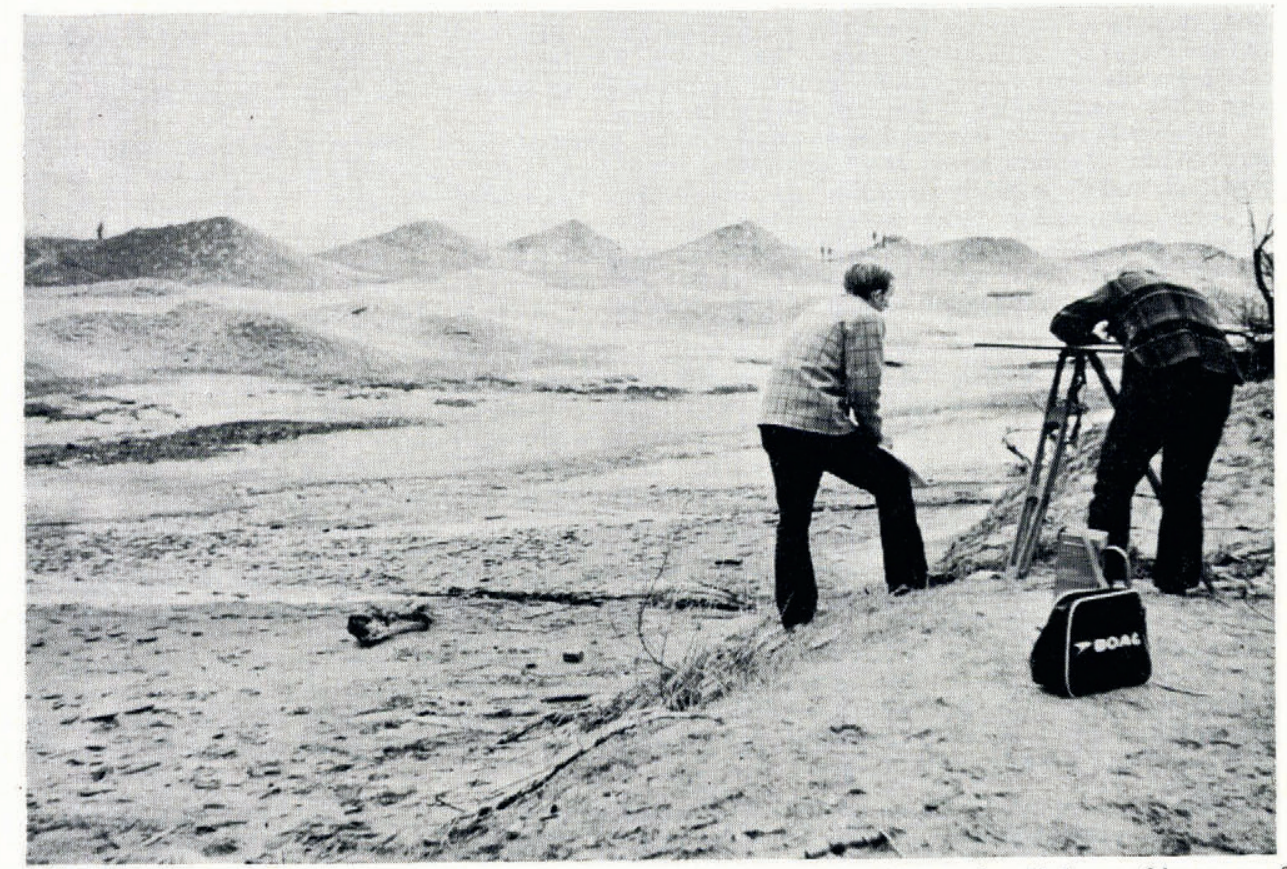

Fig. I. Ice volcanoes from the shore. There are two rows of small volcanoes near shore and a third row of large ones farther out. Note the people on the large cones for scale.

The authors have observed the cones at several localities within a few miles of Dunkirk, on the west side of Presque Isle at Erie, Pennsylvania, and at a number of points along the Lake Ontario shore from Rochester to Oswego, New York. The cones have been reported by oral communications as far west as Ashtabula, Ohio.

Although the writers may have failed to note some earlier works, certainly there is no abundant literature on the subject. We should be grateful for any communications regarding their distribution, formation or previous studies.

\section{FORM AND STRUGTURE}

Viewed from shore, the ice volcanoes appear to be simple cones, even in spacing and form (Figs. I and 2). As shown in the map cross-sections (Fig. 2) and photographs (Figs. 3, 4 and 5), the lake side of these features is much more complex. Each of the conical mounds has a central channel opening toward the lake. The channels are separated by intervening headlands which jut lakeward beyond the line of mounds. The headlands are topped by levees which slope gently away from the lake margin. At Dunkirk, headlands stand $2-3 \mathrm{~m}$ and the cones $5 \mathrm{~m}$ or more above the adjacent lake ice. 


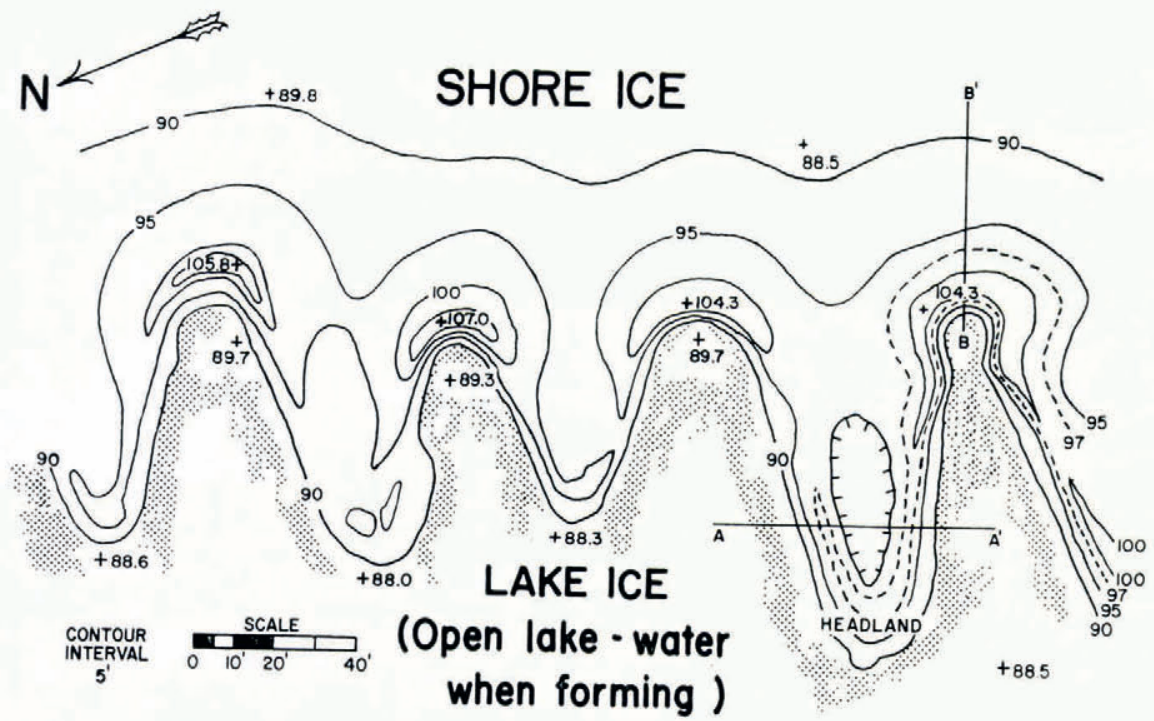

\section{ALL POINTS RELATIVE TO ARBITRARY DATUM OF 99.99 FEET $(30.47 \mathrm{~m})$}

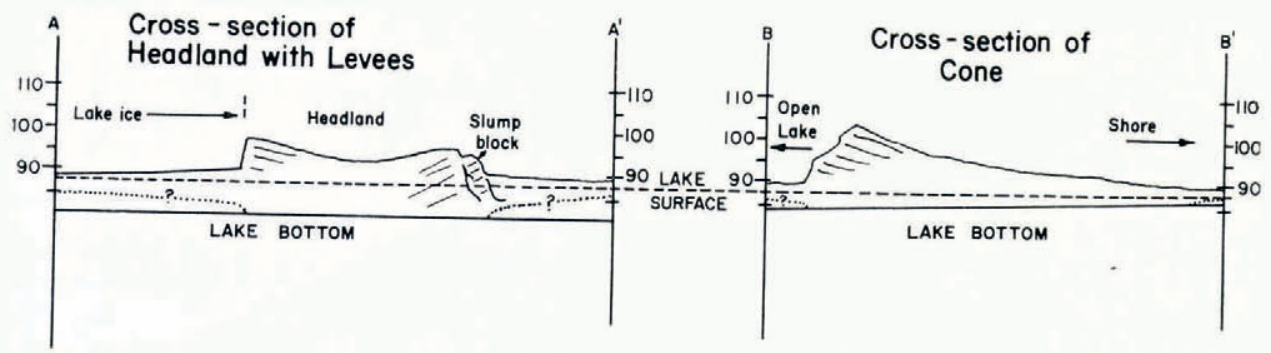

Fig. 2. Map and cross-sections of Lake Erie ice volcanoes.

The internal structure exposed in the channels and on the headlands is shown in the crosssections (Fig. 2) and in Figure 4. Layering is shown by orientated tabular ice blocks and interbedded layers of clear, white and dirty granular ice (Fig. 4). Most of the tabular blocks lay parallel to the conical surface or parallel to the gently sloping shoreward face of the headlands and levees. Silt, sand, fish, wood fragments and shale bedrock fragments (Fig. 6) are also buried within the ice layers.

\section{ORIGIN OF THE IGE VOLCANOES}

In January 1972, the authors were able to observe the ice volcanoes forming at Dunkirk (Fig. 7). At the time they started to form, the air temperature was below freezing and there was floating slush and blocks of ice in the water. The wind was blowing onshore, from the west and north-west, at about $14 \mathrm{~m} / \mathrm{s}$. The cones in the first row were small (less than a 


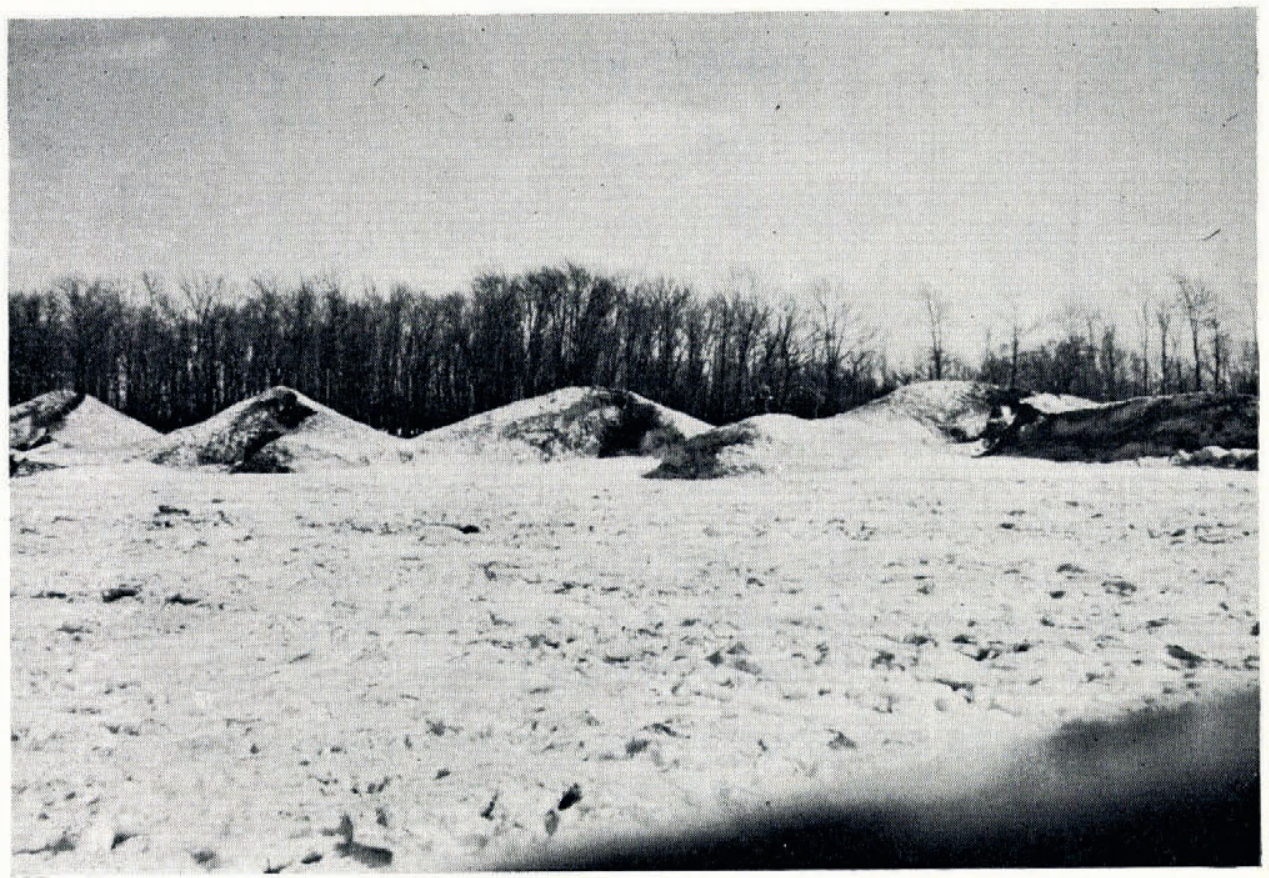

Fig. 3. Ice volcanoes from the lake side. The channels have been widened by slumping of the intervening headlands. The foreground ice formed after the volcanoes were fully developed.

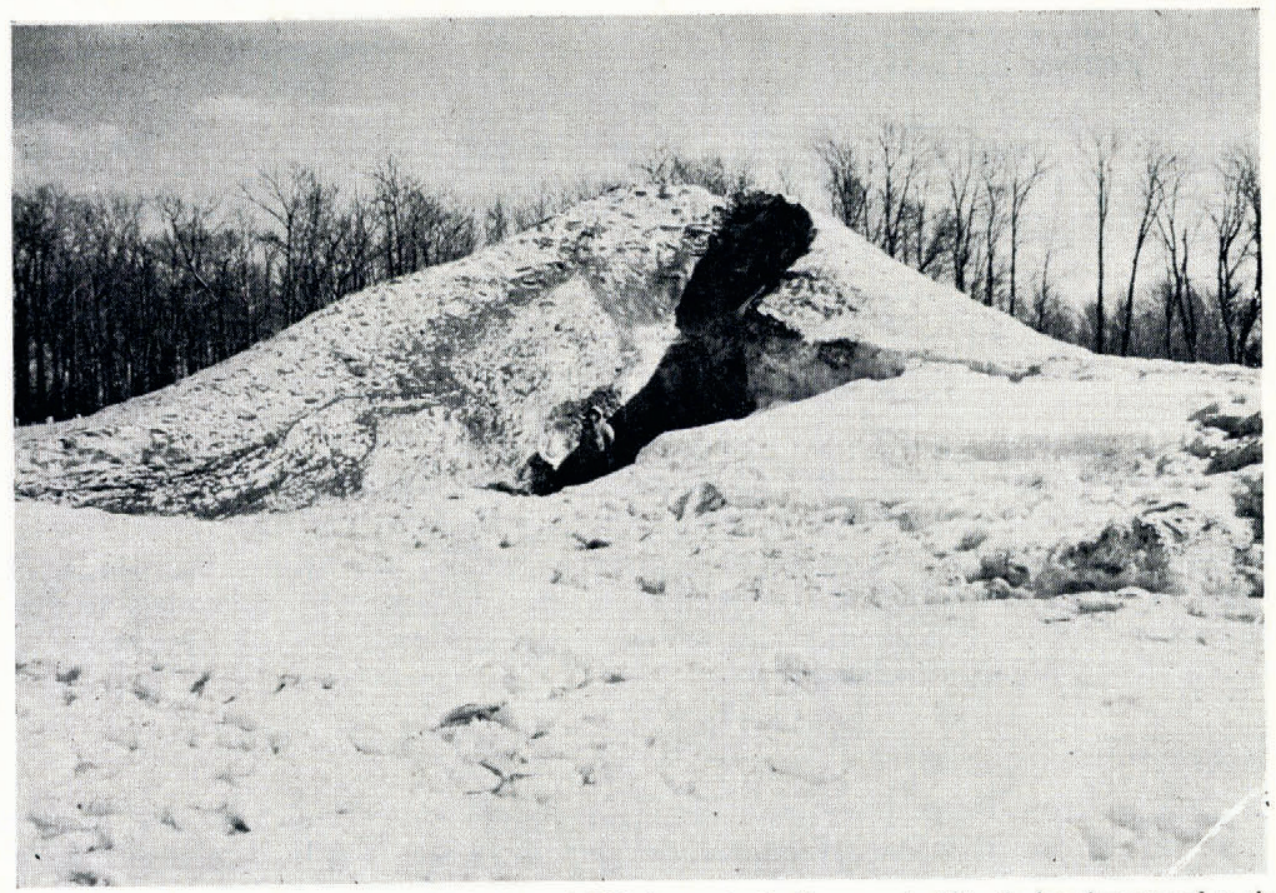

Fig. 4. The lake side of an ice volcano with lake ice and drifted snow in the foreground. Note the layering exposed on the left side of the channel in which ice cakes lie parallel to the surfaces on which they were deposited. 


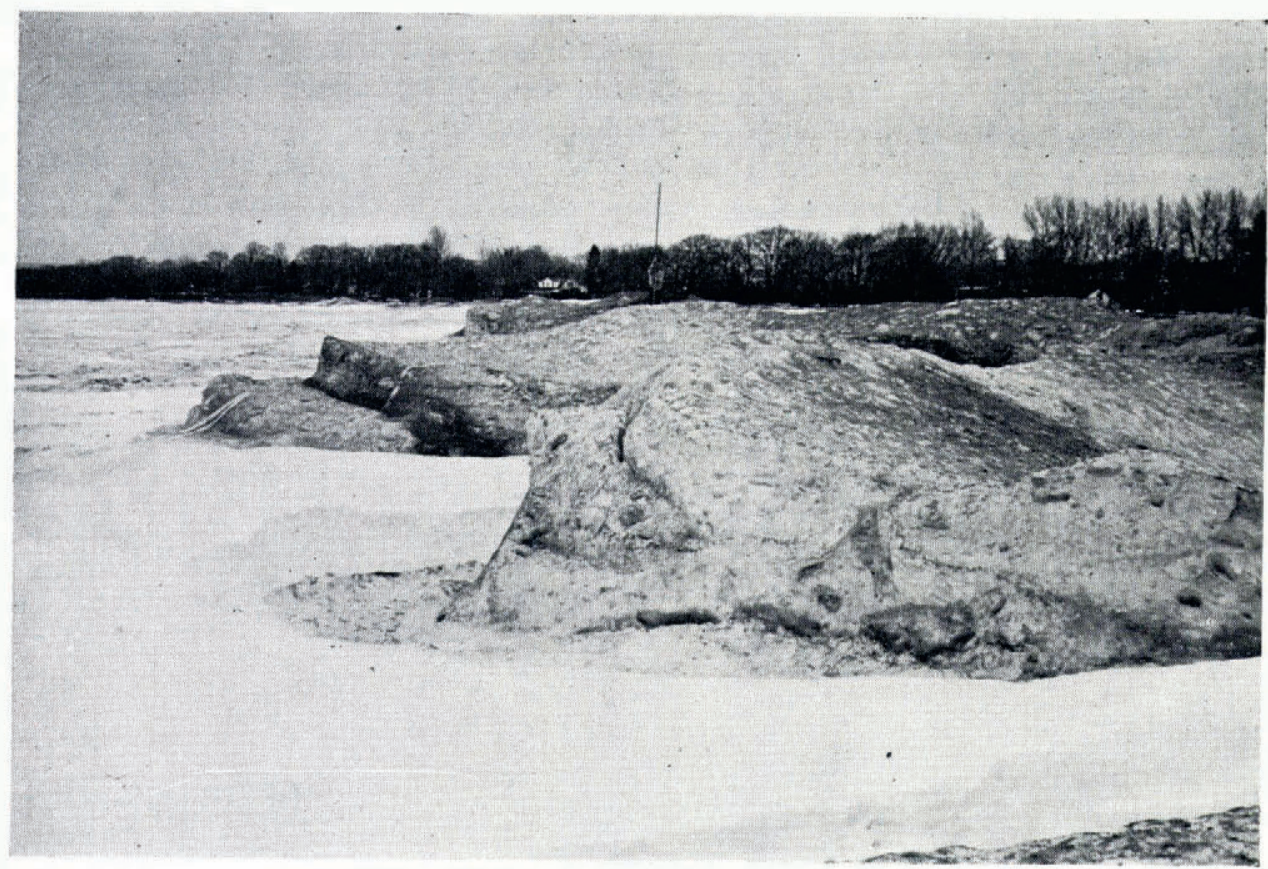

Fig. 5. The headlands. The ${ }_{14} \mathrm{ft}(4.27 \mathrm{~m})$ surveyor's rod gives a scale. Collapse of the nearest portion of the headland in the foreground gives a cross-section similar to $A-A^{\prime}$ (Fig. 2) showing internal structure and the slope of the marginal levees.

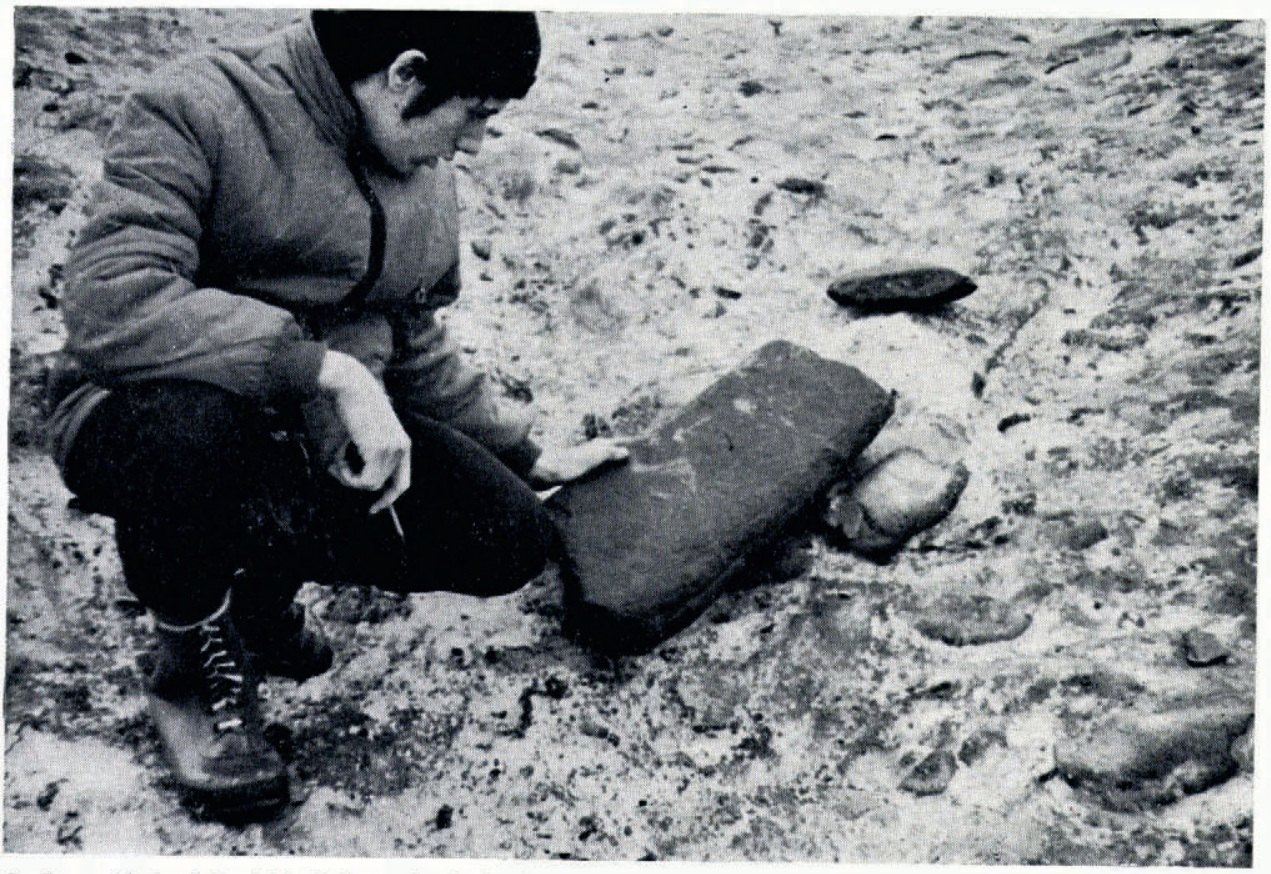

Fig. 6. Large block of Dunkirk shale on the flank of an ice volcano. Estimated weight approximately $20 \mathrm{~kg}$. This block and other small ones nearby are thought to have been derived at the base of the volcano by waves reinforced in the channel. 
meter) and irregularly shaped, and formed where the waves broke on the beach. As the wind subsided the water no longer splashed up over the cones. Instead, blocks of ice drifted into shallow water and became frozen as a shelf to the lake side of the first row of cones. A zone of shore-fast ice blocks, averaging $50 \mathrm{~m}$ wide, formed before the wind velocities again reached $14 \mathrm{~m} / \mathrm{s}$. At this time, a second line of cones began forming on the lake edge of the shore-fast ice. This second line of cones roughly paralleled the depth contours which are at a slight angle to the beach. The cones were spaced fairly regularly about $15 \mathrm{~m}$ apart and built to heights of $5 \mathrm{~m}$ overnight. Strong, onshore, wind-generated waves and above freezing air temperatures modified these cones by enlarging the channels and in some cases breaking completely through the shore side of the cones.

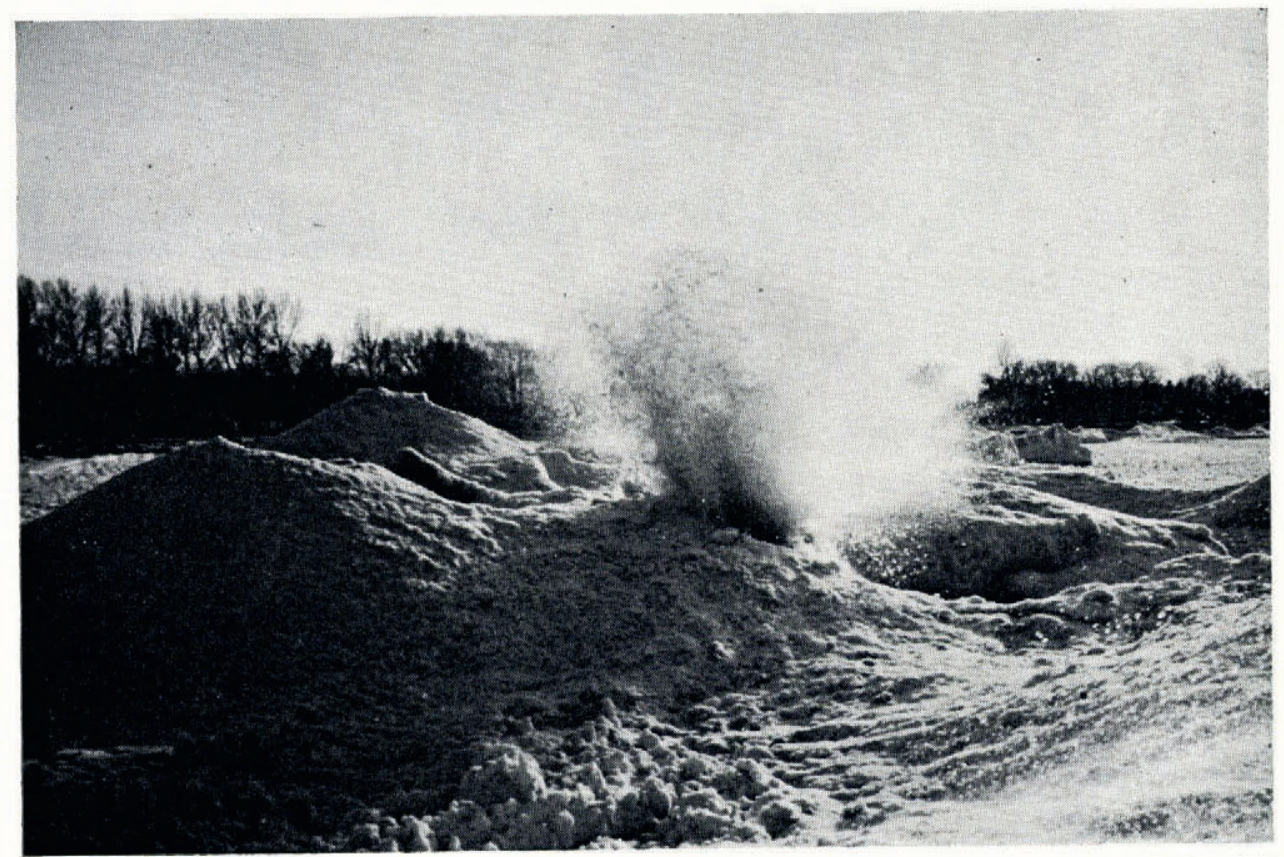

Fig. 7. Ice volcano in eruption; January 1972. A single wave might add as much as several centimeters to the height of the cone.

A third storm with onshore winds exceeding $28 \mathrm{~m} / \mathrm{s}$ raised the level of eastern Lake Erie about $1.25 \mathrm{~m}$ or more and completely broke up the cones and the zone of shore-fast ice and piled everything on to the beach. A few irregularly shaped cones formed on the beach but in general the ice was simply piled up to heights of about $3 \mathrm{~m}$. By the time the wind quieted, the water temperature was low enough that a zone of shore-fast ice formed out for a distance of about roo $\mathrm{m}$. A new line of cones was started but did not build very high before the ice completely closed in and prohibited further cone formation for the rest of the winter.

We conclude from our observations that the following factors are responsible for the formation of the ice volcanoes: (I) The air temperature must be below freezing while the water is mainly unfrozen, with only slush and a few floating ice blocks; (2) The wind direction must be onshore and the velocity greater than I I m/s; (3) Some shore-fast ice must be present for the waves to break against.

As the wind-generated waves impinge on the lake-side edge of the shore-fast ice, slight irregularities in the ice edge tend to focus the wave energy into a smaller area. The result is that slush and ice blocks are tossed up around the indentation more than along the rest of the 
ice edge. While the concentrated wave energy tends to erode the indentation, shoreward, making it a deeper and more $\mathrm{V}$-shaped channel, water and floating ice are thrown even higher around the eroded channel. As the water sprays up into the cold air, it either freezes before it falls or as it drains down the outer or shore-face slope of the resulting cone. Ice blocks and other debris thrown out of the channel are immediately frozen in place on the cone. The height of the cone is a function of the height to which the water can be thrown out of the channel.

The fairly regular spacing of the cones along the edge of the shore-fast ice may be analogous to the regular spacing of beach cusps. This suggests that the spacing might be controlled by the direction and size of the approaching waves. The exact relationship is unknown.

The headlands, which extend lakeward between the cones, are partially erosional and partially constructional features. The channels are cut deeply into the shore-fast ice and cones are built at the ends of the channels shoreward of the original position of the ice front. In addition, waves do break over the entire edge of the ice and, thus, build an ice and debris surface that slopes away from the open lake and channel edge in much the same fashion that levees slope away from a river channel. This tends to build the headlands higher and perhaps farther lakeward.

Since the row of cones and the $50 \mathrm{~m}$ or so of shore-fast ice were completely destroyed this year during a violent storm, it appears that the wind, and the wind-generated waves, can reach a point where the channels are cut faster than the cones and headlands are built. Erosion is also made easier by a higher water level which raises some of the ice from the bottom and also, perhaps, by higher temperatures, which cause some melting. The combination of these factors ultimately results in the destruction of the cones and all of the ice is broken up and either piled on shore or carried along shore. If this happens just before the lake begins to freeze more solidly, it is possible that a new line of cones will not be built. This, of course, would vary from year to year as does the size of the cones and the numbers of rows of cones. If several rows of cones remain in place, they tend to protect the shoreline from erosion during winter storms.

MS. received 6 April 1972 